\title{
Vivian Sobchack
}

\section{„Én, engem és magam”: A home movie kísérteties hatásáról}

\begin{abstract}
Absztrakt
A home movie attitúd egyike a filmes identifikáció Jean-Pierre Meunier által megjelölt három modalitásának, amellyel $A$ filmes tapasztalat struktúrái: a filmes azonosulás (Les Structures de l'expérience filmique: L'identification filmique, 1969) címû́ kötetében foglalkozik. Jelen esszé egyrészt próbára teszi ezt az elméletet, másrészt pedig lerója tiszteletét Meunier heurisztikus fenomenológiai meglátásai elôtt. Azokra az esetekre koncentrál, amelyekben a home movie nézôjének képernyôn kívüli énképe [self-image] hirtelen találkozik a képernyőn szereplő képi önmagával [image-self]: ezen azonosulás szerkezete pedig egészen különbözik azoktól az esetektôl, amikor a képernyôn megjelenô más személyekkel azonosulunk. Gyakran kisértetiesként éljük meg ezt a helyzetet, így ez nem csupán egy apró különbség, hanem akár át is alakíthatja azt, amit Meunier a home movie tapasztalat alapvetố jellemzôjének és általános fenomenológiai tapasztalatának tart.
\end{abstract}

\section{Szerző}

Vivian Sobchack a Los Angeles-i Kaliforniai Egyetem (UCLA) professzor emeritája, 1992 és 2005 között a Színház, Film és Televízió Intézet dékánhelyettese és oktatója. A '90-es évek elején The Address of the Eye: A Phenomenology of Film Experience (Princeton University Press, 1992) címú kötete középponti szerepet játszott abban, hogy a fenomenológia mint módszertan visszanyerje pozícióját a filmtudományban. Késóbb a Carnal Thoughts: Embodiment and Moving Image Culture (University of California Press, 2004) címú munkájában a mozgóképi médium egzisztenciálisfenomenológiai megközelítését dolgozta ki. A Toward Phenomenology of Non-Fictional Film Experience (1999) címú esszéje volt az első olyan angol nyelvú szöveg, amely jelentôs magyarázatként szolgált Jean-Pierre Meunier filmi identifikációról írt fenomenológiai megközelítéséhez. Ô volt a Film- és Médiatudományi Társaság (Society for Cinema and Media Studies) elsố nôi elnöke (1985-1987), és 2012-ben a Distinguished Career Achievement Award díjjal tüntetették ki. Két évtizeden át tevékenykedett az Amerikai Filmintézet (AFI) igazgatótanácsának egyedüli akadémikusaként is.

https://doi.org/10.31176/apertura.2021.16.2.7 


\section{Vivian Sobchack}

\section{„Én, engem és magam”: A home movie kísérteties hatásáról}

I.

A home movie attitûddel létrejövô nézői azonosulás jelentésérôl és annak meghatározó fenomenológiai szerkezetérôl szóló összegzésében Jean-Pierre Meunier fontolóra veszi, hogy a home movie szándéka és célja eleve lehetetlen és egyben hiábavaló is. Ezalatt azt az intenciót érti, melynek lényege, hogy valahogy „felidézzük” és ,jelenvalóvá tegyük” a magunk számára azokat a családtagokat és barátokat, akik egykor a kamera képernyốn kívüli terében léteztek - illetve, hogy még teljesebb módon megtapasztaljuk ôket, mint az adott home movie-ban vagy téridốben, amelyben jelenleg csupán „emlékképként” látjuk ôket. Valójában a fizikai hiányukról és az idôbeli távolságukról való egzisztenciális tudásunkon az a vágyunk kerekedik felül, hogy itt és most velük legyünk, méghozzá olyan formában, ahogy és amilyenek korábban voltak. A home movie attitûd esetében ahelyett, hogy a film konkrét képeit szemlélnénk, keresztülnézünk rajtuk: ezáltal pedig kísérletet teszünk arra, hogy ezeket az egyéneket általánosságban idézzük fel és tegyük „ismét jelenlévôvé” óket egy jelenbeli - ám paradox módon mégis múltbeli - újraegyesülésben, amelynek mi magunk is szerves részét képezzük. A „személy jelenvalóvá tételéhez” fúzôdô vágy egyik pólusaként Meunier azt hangsúlyozza, hogy „gyakran a saját jelenlétünk a másik személy számára az, amit megpróbálunk felidézni.” (1969: 104) Csakugyan, „a valódi interszubjektív kapcsolatot keresve”, „saját jelenlétünk [az], amelyet folyamatosan érzünk.” (1969: 104)

Az interszubjektivitás megvalósulása a home movie attitûd esetében természetesen lehetetlen. A nézô sikertelen felidézési és újraegyesítési kísérlete nemcsak csalódáshoz és kompenzációs nosztalgiához vezet, hanem az identifikációs projekt egzisztenciális abszurditásának érzetéhez is. „A személyes elköteleződésre irányuló törekvésünk” - írja Meunier - „szembekerül az ürességgel, és felfüggesztve marad, minden lehetséges kiút vagy valódi jelentés nélkül.” (1969: 104) Mivel „képtelenek vagyunk elkötelezôdni”, önnön jelenlétünk nyilvánvalóvá válik, és így „egyre inkább a jelenlétünket érezzük, [és hogy] önmagunkkal vagyunk elfoglalva.” Összegezve, mivel nézóként oly módon próbálunk meg kapcsolatot teremteni ismerôseinkkel, ahogy „egykor” és „máshol” voltak (még akkor is, ha némelyikük most is „úgy van” velünk egy térben, mint ahogy a filmben látható), bizonyos értelemben mindig is már a megfosztottság állapotában vagyunk orvosolhatatlanul és abszurd módon egyedül önmagunkkal a képernyố egyik oldalán. ${ }^{[1]}$ Mindazonáltal a home movie attitûd részeként tapasztalt, „önmagunkkal való foglalkozásról” [" self-preoccupation”] többet is el lehet mondani. Meunier elismeri, hogy „sok árnyalattal lehetne 
gazdagítani e problémát, illetve számos konkrét esetet is meg kellene vizsgálni hozzá.” (1969: 105) A következôkben egy sajátos esetét vizsgálok meg, amely árnyalja ezt a kérdést, és egyben kihívást is jelent a home movie-s tapasztalat Meunier által lényeginek tekintett sajátos fenomenológiai struktúrája számára. Ez az a korántsem szokatlan eset, amikor a néző „szemtól szembe” kerül a saját, képernyốn látható képmásával, amely az azonosulás kísérteties tapasztalatát váltja ki. Mivel azonban szoros párbeszédet folytatok Meunier fenomenológiai sémájával és filmes korpuszával, illetve át is veszem azokat, még mielôtt elemzésem részleteibe merülnék, szükséges két olyan módszertani kérdéssel foglalkoznom, amelyek meghatározzák a jelen vitát.

Az elsô kérdés azon filmtárgyak természetére és hatókörére vonatkozik, amelyeket Meunier - a nézővel együtt - a home movie attitúdöt alkotó mozzanatnak tekint. A home movie-k [Meunier fogalomhasználatában: le film-souvenir] olyan filmek, amelyek „magáncélra készültek, azzal a szándékkal, hogy az egyén életének egy-egy eseményérôl, például esküvôroól, nyaralásról, családi összejövetelekról emléket állítsanak vagy felvételt készítsenek." (Hanich 】Fairfax 2019: 155-156. 34es lábjegyzet) E korpusz átvétele lehetôvé teszi számomra, hogy a saját fenomenológiai változatomat Meunier leírásaival egyezóen, illetve azzal szemben is megalapozza, és egyben le is határolja azt, amit ha kiterjesztenénk, egy újabb igen jelentôs - és nehézkes - változó lenne. Bár a kizárólag „magáncélra” készült filmek csoportja ma már kissé elavult leírásnak túnhet, Meunier korpusza kulturális szempontból még ma is releváns. Kétségkívül, amikor 1969-ben elôször jelent meg A filmes tapasztalat struktúrái: a filmes azonosulás (Les Structures de l'expérience filmique: L’identification filmique), a hétköznapi emberek még nem úgy járták a világot, mint mi most, folyamatosan rögzítve mindent, amit csak látunk - beleértve saját magunkat is - mind a nyilvános, mind a magánfogyasztás céljával. Sôt, a Super 8-as filmkamerák csupán négy évvel Meunier fenomenológiai kötete elôtt jelentek meg a tömegpiacon. (A videokazetta a 80-as évek közepén, a digitális videokamerák a 90-es évek közepén, az okostelefonok pedig a 2000-es évek elején kerültek tömegesen forgalomba.) Meunier korpusza így olyan típusú filmekre vonatkozik, amelyeket többnyire a nem szakmabeliek készítettek. Az ilyen típusú filmek ma is mindennaposak, és a technológiailag kiterjedt audiovizuális kontextusban [akárcsak készítóik [ egyre inkább elérhetôvé válnak a nyilvánosság számára is. Így bizonyos, alább tárgyalt esetekben az állandó személyes rögzítés és a képernyốn való „ismerôs” láthatóság meggátolhatja az általam elótérbe helyezett, kísérteties home movie élményeket. 


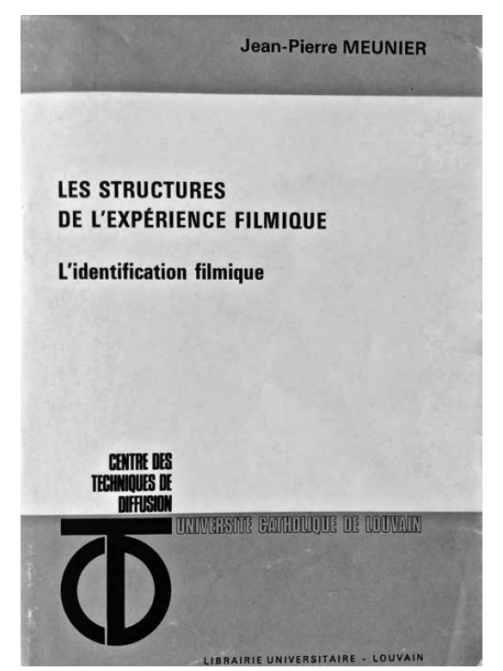

Jean-Pierre Meunier: Les Structures de l'expérience filmique:

L’identification filmique (1969)

A második módszertani kérdés mind a fordítás, mind a terminológia területét érinti. Ahelyett, hogy a megszokott és inkluzívabb film amateur megnevezést használná, Meunier általánosságban film-souvenirnek nevezi a korpuszát (ezt a terminust nem találtam meg a francia szótárakban). Ez a látszólagos neologizmus azon filmtárgyakat helyezi elôtérbe, amelyek elsôdlegesen az emlékezethez folyamodnak: a kötôjel egyszerre kapcsolja össze és választja el óket a személyes emlékezés szubjektív aktusaitól. ${ }^{[2]}$ Bár a film-souvenir elsôbbséget élvez egy korábbi, Meunier munkásságáról írt esszémben, jelen írásban az angol megfelelôjét, a „home movie-t” részesítem elônyben. ${ }^{[3]}$ Bár a személyes emlékezés mellékjelentései így elveszhetnek, viszont megkapjuk az „otthon” konnotációit: különösen az otthonosság, az intimitás és a kellemesség érzése az, amelyet a kísérteties érzése felforgat. Ebben a kontextusban az „otthon” szó felidézheti a kísérteties német megfelelöjét, az „unheimlich” fogalmát, amely egyben az „otthon” ellentétpárja is, hiszen szó szerinti fordítása: „nem otthonos”. A kifejezés olyan élményt jelöl, amelyben az ismerôs dolgok hirtelen zavaróan különössé és titokzatossá válnak - továbbá e fogalom szorosan kapcsolódik a jelenségrôl szóló kulcsfontosságú pszichológiai és filozófiai tanulmányokhoz (amelyek közül háromra késôbb itt is hivatkozom). A következôkben azonban inkább egzisztenciális fenomenológiáról, mintsem pszichológiai etiológiáról, pszichoanalitikus magyarázatról vagy filozófiai extrapolációról lesz szó, ezért az általánosabb „kísérteties” [,uncanny”] kifejezést fogom használni. Kétségkívül ez a terminus „otthonosabb” lehet azok számára, akik egzisztenciálisan megtapasztalják az elidegenedést abban az amerikai kulturális kontextusban, amelyet ez a fenomenológia leír.

\section{II.}

Most tehát térjünk rá azokra az esetekre, amikor egy home movie-ban látjuk magunkat; amikor az objektív „képi én” és a szubjektív „énkép” közti egzisztenciális szakadékban, az „én” [„I”] hirtelen 
szembekerül magammal [,me”]. Ez egy olyan identifikációs találkozás, amelyet a nézôk jelentős része kísértetiesnek tart, elsôsorban a zavarba ejtôen aszinkron jellegú megfordíthatóság és az elbizonytalanító megkettôződés miatt. Bár elég gyakori ahhoz, hogy a nyilvános diskurzusban elôkerüljön, természetesen ez a tapasztalat nem szükségszerúen következik be. Különösen akkor tûnik kevésbé valószínûnek, amikor a néző saját maga hozza létre az „önreprezentációját”, akár a fürdôszobai tükör elốtt, akár Skype-videóhívások, YouTube-videók és szelfik formájában. ${ }^{[4]}$ Ilyen esetekben a nézônek jobban sikerül megôrizni az „önbirtoklás” viszonylag nyugodt érzését. Más a helyzet azonban azon személyek esetében, akik home movie-kban látják viszont önmagukat, és nem „önreprezentációval”, hanem egy zavaró, „magukról készült reprezentációval” találkoznak: ez utóbbit valaki más (még ha az közeli barát vagy családtag is) ágenciáján és filmes érzékelésén keresztül filmezték és szûrték át.

A képernyőn történő, önmagunkkal való ilyetén találkozás hirtelen kettéosztja az általában világos „egységes én” érzetünket: egy észlelő „Énre” és egy látható „magamra”. Ezzel összefüggésben Maurice Merleau-Pontyhoz fordulok, akinek a fenomenológiai meglátásai jelentôs mértékben befolyásolták Meunier elméletét is. Merleau-Ponty kifejti, hogy „a testemet egyfajta felfeslés eleve megkettôzi és felnyitja, látóvá és látottá, érintővé és érintetté változtatja, és e két rész átfedi egymást, egymásba csúszik." [5] Ezen bensôséges filmes újraegyesülésben öntudatunk elidegenedetté válik: ez az újraegyesülés egyben szétválás is (és fordítva). A képi én és az énképem átfedése és betolakodása aszinkron különbözőségükben és a nem egybeesố megfordíthatóságukban nem csak hogy állandóan foglalkoztat engem (vagy „én-t” kéne mondani?), hanem kimozdít és el is bizonytalanít engem (vagy „minket”?). Sok nézô ezt kísértetiesként tapasztalja meg.

Természetesen ez az önmagunkkal való foglalatoskodás megerősíti azt a fenomenológiai mozzanatot, amelyet Meunier a home movie attitúd lényeges elemének tart. Ugyanakkor ha valaki más képe helyett a saját képi énünket nézzük, érvénytelennek túnik Meunier meglátása a home movie alapvetô fenomenológiai funkcióját illetôen: vagyis az, hogy a home movie olyan médiumként szolgál, amelyen keresztül konstitutívan általánosítjuk és transzcendáljuk a képernyôn látható, általunk részletesebben ismert személyek sajátosságait. Valójában saját, képernyőn megjelenô képünk 【még akkor is, amikor inkább kellemesnek vagy viccesnek, semmint kísértetiesnek tûnik ] hajlamos arra, hogy kiváltsa a saját magunkkal való foglalatoskodást, mivel az ontikus „máshol” [, thereness"] ellenáll az általánosításnak és a transzcendenciának. Amikor azonban a kísérteties érzését tapasztaljuk, a „máshol” makacs átlátszatlansága felerôsíti és kiváltja a kísérteties három lehetséges modalitását, amelyek mindegyike másképpen strukturált, ezáltal különbözô módon tapasztalható meg, illetve más-más reakció adható rájuk.

Az elsô modalitást axiologikus kisértetiesnek nevezem. Ez az önészlelésünk válságaként azonosítható, amely inkább önmagunk reprezentációjával kapcsolatos és kevésbé a home movie krízisével, azaz mások megvalósíthatatlan ,jelenvalóvá tételével”. A második az episztemológiai kisérteties, amely az önismeret kognitív krízise. A harmadik típus, az ontológiai kisérteties pedig az önazonosság egzisztenciális válsága. Fokozatos elmozdulás figyelhetô meg tehát attól a váratlan és nyugtalanító 
érzéstôl, hogy az ember csak részben ismerheti önmagát, a hirtelen újrafelismerésen át, hogy az ember részben mindig ismeretlen marad önmaga számára, a mindent felforgató felfedezésig, hogy az ember végsố soron megismerhetetlen saját maga számára. Mindvégig 【csakúgy, mint a képernyốn megjelenố többi ember esetében [a saját létezésünket „valóságosnak” tételezzük. Tekintettel azonban arra, hogy mindannyian mind kívülrôl, mind belülrôl megéljük önmagunkat, azt feltételezzük, hogy sokkal közelebbrôl és teljesebben ismerjük, mint akár a hozzánk legközelebb álló ismerôseink létezését.

Ezt a feltételezést az aszinkron idő középponti szerepe kérdőjelezi meg a home movie-s tapasztalat esetében. Vagyis amikor a képen kívüli „én” találkozik a képen megjelenő önmagammal, az idô térbelivé válik azáltal, hogy a múltbeli képi énem láthatóan különbözik attól a megjelenéstôl és viselkedéstôl, amelyet a jelenlegi énképemként képzelek el. Miközben ez az aszinkron eltérés nosztalgikus érzést kelthet, olyan kísérteties élményt is kiválthat, amely során a nézô általános önismerete és önbirtoklása hirtelen bizonytalanná válik. Azt gyaníthatnánk, hogy minél nagyobb az idôbeli távolság a képi én és az énkép között, annál nagyobb mértékú lehet az előbbitôl való elidegenedés, és annál intenzívebb a kísértetiesség „érzete” is. Mindazonáltal, amikor a képi én és az énkép idôben a legközelebb állnak egymáshoz, akkor a legerôsebb a kísérteties „érzékelése”. Itt az érzet és az érzékelés nem azonos idôbeli struktúrával rendelkeznek az elôbbit az idôtartam, a másikat a közvetlenség jellemzi. Az idô így módosítja a kísérteties minôségét [amely a hirtelen zavar érzékelésétôl az önmagunktól való elidegenedés reflektáltabb (bár még mindig nyugtalanító) újrafelismerésén át annak az átfogó, egzisztenciális megértéséig tart, hogy az ön-elidegenedés, valamint az önbirtoklás hiánya az egyén létének alapvetô meghatározottsága. (Ez a folyamat némileg kapcsolódik a kísérteties azon pszichológiai értelméhez, amely Sigmund Freudhoz és a korábbi Ernst Jentsch-hez kötôdik, illetve Martin Heidegger filozófiai megközelítéséhez: mindezekre az alábbiakban a kísérteties tapasztalat egyegy sajátos módjának leírásában utalok. ${ }^{[6]}$ )

\section{III.}

Az axiologikus kisérteties elnevezés onnan ered, hogy ezt a tapasztalatot az esztétikai ítéletek és az önértékelés kérdései határozzák meg. Ez abban a váratlan hézagban jön létre, amely a néző belsôvé tett és adottnak vett énképe, illetve az objektivált, arcába vágott képi énje között keletkezik, leggyakrabban pedig akkor fordul elô, amikor e kettố idôben közel áll egymáshoz. (Általában hasonló rés képzôdik a képi én külsôleg reprezentált hangja és az énkép belsôleg hallott hangja között.) Ami azonban a leginkább kísérteties és kizökkentô, az az, amikor a nézôben a szubjektív önészlelése és az objektív reprezentációja közti eltérés hirtelen tudatosul. Az axiologikus kísérteties felbukkanása tehát nem csupán a nézônek a saját önismeretével kapcsolatos bizonyosságát ássa alá, hanem az interszubjektivitással kapcsolatban is kétségeket vet fel, és megcáfolja az ebbe vetett hitet is, amely egyébként a home movie attitúdöt megalapozza. A nézô 
magában azt a kérdést teszi fel, „Ez tényleg én vagyok?” és „Mások tényleg így látnak engem?”

Ebből a szempontból az axiologikus kísérteties a szó szoros értelmében a legfelületesebb modalitás, illetve ebben az esetben a leginkább nyilvánvaló a nézô saját magával való foglalatoskodása. E modalitás megjelenésekor túlnyomórészt a képi énre irányuló fokozott figyelem és annak túlzott, részletekbe menô vizsgálata a jellemzó. Így a home movie attitúd alapvetô identifikációs szerkezetével szemben, a nézố tevékenysége nemcsak hogy nem konstitutív, de nem is kiterjedtebb annál, mint ami a képernyőn látható. Az axiologikus kísérteties tehát teljesen képernyőfüggố. Valójában az általánosítás konstitutív tevékenységét az összehasonlítás váltja fel, mégpedig a képi én külsô jellemzői és a belsôleg érzékelt - de immár kétségbe vont -, az énképet alkotó jellemvonások összevetése. Ennek megfelelôen ez az összehasonlítás folyamatos esztétikai és személyes értékelést is maga után von, amelynek célja a nézô önmagával való megbékélése vagy az én helyreállításának valamilyen formája.

Bár a nézô tekintete a képernyôre rögzül, Meunier home movie attitúdjének központi eleme, a longitudinális intencionalitás is fennmarad. Ez a nézés jelen pillanatába való elsôdleges érzelmi befektetést jelöli, amelyben a retenció és a protenció nem játszik nagy szerepet. Mindazonáltal a nézô rossz közérzete módosíthatja az érzelmi befektetés minôségét. Ezt nagymértékben fokozza a képernyôn látható képi én alapos megvizsgálása és a látottak (általában) negatív megítélése. A „Kényelmetlen érzés, ha magadat nézed egy videón?” címú online fórumon sok hozzászóló azt írta, hogy „utálja” magát nézni, mert, ahogy a legelsô hozzászóló fogalmaz, „Egyszerúen nem úgy nézek ki, ahogy ÉN AZT GONDOLOM, hogy kinézek [...] szó szerint feszengek, amikor látom magamat [...] alig ismerem fel magamat [...] nagyon furcsák a kifejezéseim és a szükségesnél többet mozgatom a fejemet." Szinte az összes válaszadó egyetért abban, hogy - ahogyan egyikük írja „utálom a hangomat és az orrom beteríti az arcomat”, egy másik pedig így fogalmaz: „Nem bírom elviselni, hogy videón nézzem vagy halljam magamat [...] Az jár a fejemben, hogy »Istenem, tényleg ennyire rosszul nézek ki? «." Csupán néhány kommentelônek nem volt ehhez hasonló tapasztalata. Mindazonáltal, ahogy arra már korábban is utaltam, mindannyian felvették magukat videóra, így pedig az „önbirtoklás” tevékenysége révén kellóképpen „otthonosnak” érezték, hogy „birtokolják” a képernyôn látható képi énjüket. Az egyikük „színész/filmrendező”; másvalaki „MINDENT felvett” és feltöltötte a YouTube-ra, ezáltal pedig „eléggé hozzászoktam ahhoz, ahogyan kinézek és hangzok”; egy másik hozzászóló pedig, aki egyébként „szörnyúnek” tartja saját képi énjét, hozzáteszi: „Szerintem jól nézek ki, ha én magam veszem fel a videót.” [7]

Ebból a szempontból az axiologikus kísérteties, mint az önmagunkkal való foglalkozás sajátos formája, megváltoztatja a nézô általános intencionális irányultságát vagy célját azáltal, hogy megfordítja annak irányát. Meunier számára a home movie attitúd szempontjából lényeges, hogy a nézô „valódi interszubjektivitásra” törekszik a képernyốn látható személyekkel - még akkor is, ha e törekvés eleve kudarcra van ítélve. Az itt tárgyalt esetben azonban a nézố célja ehelyett a „valódi intraszubjektivitás” „saját magával” - azaz átfedés vagy beavatkozás helyett az elidegenedett képi ént próbálja meg meghitten integrálni a jelenleg ismert énképbe. Ezen integráció elérése szintén eleve kudarcra van ítélve, mivel az a mögött munkáló vágy a teljes mértékben birtokolt és 
„egységes” én fantáziája - egy olyan fantazmagória, amelyet a kisérteties másik két modalitása fokozatosan fel-ismer [re-cognize] és szerte-foszlat [dis-solve]. A nézók tehát a legjobb esetben is csak úgy érhetik el az azonos értékúségnél kisebb mértékben egymásnak megfelelô énképük és képi énjük kibékítését, hogy fel-oldják e kettő közötti ellentmondást.

A megfeleltetés során e kibékítésre tett kísérlet leggyakrabban olyan felszíni különbségekre összpontosít, mint például a frizura vagy a testsúly, amelyek a képi én és az énkép közti idôbeli hézaghoz kapcsolódnak, és amelyek feltehetôleg a hézag „okaként” is szolgálnak. E különbségek nem jelentenek olyan nagy egzisztenciális eltérést, ezért inkább arra használatosak, hogy „kimagyarázzák” a kísérteties érzését, mintsem arra, hogy elidőzzenek az önészleléssel és az önismerettel kapcsolatos kihívásokon. A kísérteties tapasztalatának csillapítását, illetve a képen kívüli és a képernyôn látható Én teljes körû egységesítésére tett kísérlet kudarcának elfojtását sok nézố azonban úgy hajtja végre, hogy felvesz [ahogy Meunier a kései francia filmológia kapcsán fogalmaz - „egy bizonyos tudományos attitûdöt [...], amely abból áll, hogy [...] externalizál, kívülrốl megfigyelhetô, objektív valóságok területére helyez ki olyan jelenségeket, amelyek valósága belül, a szubjektum tapasztalatában található.” (1969: 2) Az ilyen „tudományos attitúd” alkalmazásakor a nézô nem ismert személyeket idéz fel, hanem olyan személytelen szakértôket idéz meg, akiknek a nézô tapasztalatára vonatkozó magyarázatai objektívek. Ezek valószínúleg a „kísérteties völgy” [” uncanny valley"] (Jentsch és Freud hatását mutató) hipotézisére utalnak: ez az elnevezés azt a negatív érzelmi reakciót jelöli, amelyet az emberhez nagyon, ám mégsem eléggé hasonlító humanoid robotok tudnak elôidézni; és/ vagy a „puszta kitettségi hatás” [„mere-exposure effect”] hipotézisre, amely szerint a tükörképünknek való ismételt kitettség miatt válik a képernyôn megjelenô képünk kísértetiessé, mivel ez utóbbi fordított a mindennap látott, ismerôs arcunkhoz képest. ${ }^{[8]}$

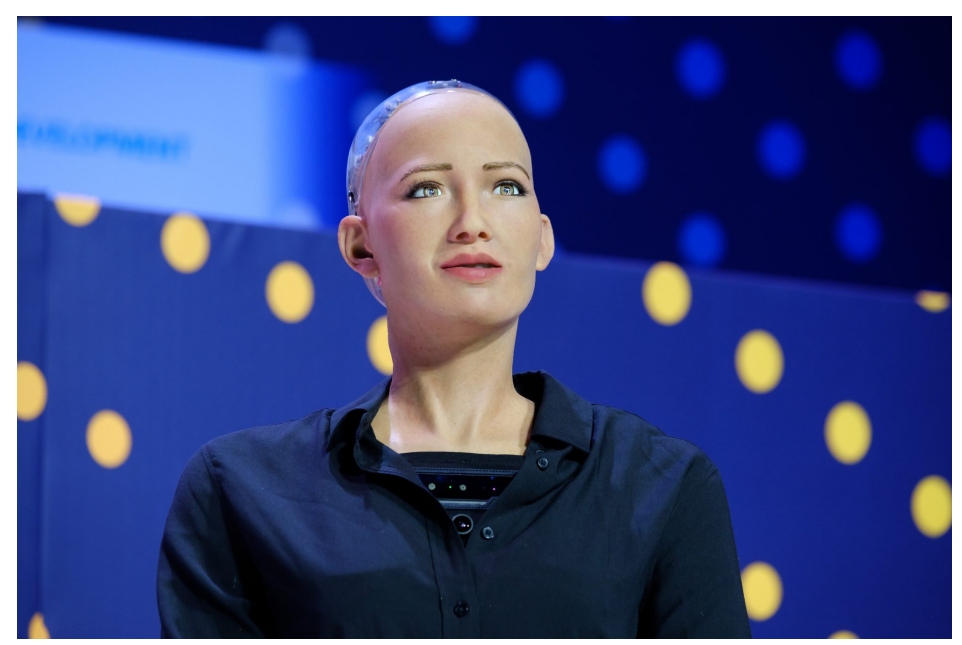

$A$ „kisérteties völgy” elnevezés azt a negativ érzelmi reakciót jelöli, amelyet az emberhez nagyon, ám mégsem eléggé hasonlitó humanoid robotok tudnak elöidézni.

A jelenségek ezen objektív értelmezései „kimagyarázzák” a kísérteties érzését; racionális bizonyosságuk inkább enyhítô és megnyugtató. Ennek ellenére sok nézô számára az axiologikus 
kísérteties élménye visszatérô és olyannyira ismétlôdôen zavaró, hogy inkább mindenestôl kerülik azokat az alkalmakat, amikor home movie-kat nézhetnének meg. Ahogy az egyik imént idézett hozzászóló írja, „Még az esküvôi videómat sem nézem meg.” [9]

Az ilyen vetítések elkerülése azonban határozottan nem az episztemológiai kisérteties élményére adott válasz - sôt, épp ellenkezóleg. Bár a nézô eleinte idegenkedik a home movie-s képi énjétôl, a kísérteties ezen modalitását nem az a vágy uralja, hogy elmeneküljön attól, hanem hogy újra felismerje azt, azaz megismerje és „megértse” azért, hogy visszanyerje az önbirtoklás érzését. Sôt mi több, mivel az episztemológiai kísérteties általában akkor jelentkezik, amikor a képi én idôben jelentôsen eltávolodott a nézô jelenlegi énképétôl, a néző elkötelezôdése kevésbé képernyőfüggó, mint az axiologikus kísérteties esetében, illetve idôben nem túnik annyira sürgetônek sem. $\mathrm{E}$ temporális távolság térbeli távolsággá is válik. Ez azt jelenti, hogy a nézô figyelme a szó szoros értelmében kiterjed a képi én legapróbb részleteinek és észlelt esztétikai hibáinak fürkészésétôl a gesztusok és a szélesebb kontextusban vett viselkedés vizsgálatáig. Ráadásul ez nem összehasonlító tevékenység, illetve a néző elsôdleges célja nem a lehetetlen interszubjektivitás a képernyőn látható személyekkel vagy a lehetetlen intraszubjektivitás, amely a képi ént és az énképet teljes mértékben egyesíti. Valójában ez a térbelivé vált idôbeli távolság átalakítja a nézô home movie attitúdjét egy olyan magatartássá, amely nagyon hasonlít - ám nem teljes mértékben azonos Meunier-nek a „dokumentumfilmes attitúdről” adott leírásához: ebben a cél többek között az, hogy olyasvalakirôl szerezzünk új ismereteket, aki egzisztenciálisan „valósnak” van tételezve, de nem azonos a nézôvel. (Hanich 【Fairfax 2019: 124) Az attitûd és a szándékolt cél ezen átalakulása miatt a home movie-t idôbeli szempontból már nem csak longitudinálisan fogjuk fel, vagyis amikor a retenció és a protenció alá van rendelve a nézés minden egyes pillanatának, mivel ez irreleváns ahhoz, hogy felidézzük a távollévôket, akikrôl több ismeretünk van, mint amennyit a képernyốn megjelenô képek nyújtanak számunkra. A kísérteties képi énünkkel szembesülve, amely bár nyilvánvalóan ismerôs, hirtelen mégis távolinak és ismeretlennek tûnik számunkra, a home movie-t már nem csupán longitudinálisan, hanem Meunier értelmében „laterálisan” is érzékeljük az időben. (Hanich [Fairfax 2019: 108) A dokumentumfilmes attitűdhöz hasonlóan a néző figyelme továbbra is a képernyő jelenére irányul, ugyanakkor erôsen lefoglalja a képernyőn látható múltbéli információk retenciója is - bár nem foglalkoztatja az elôrevetített jövô. Önmagunk megismerése (amirôl azt gondoltuk, hogy már ismerjük) kumulálódó folyamattá válik, amelynek nincsen szükségszerúen teleológiája. Az episztemológiai kísértetiesre adott reakció, hogy a nézô mondhatni saját képi énje „tanoncává” válik: nem abból a célból, hogy arra összpontosítson, hogyan néz ki vagy miként beszél, hanem hogy többet tudjon meg arról, ô maga miként viselkedik az ốt körülvevô világban, illetve másokkal.

Az episztemológiai kísérteties kapcsán tehát a nézô tudatos célja az, hogy megértse a múltbéli képi énjét, nem pedig, hogy azt teljes mértékben integrálja a jelenbeli énképébe. A nézó tiszteletben tartja a kettő közti egzisztenciális távolságot, ezért a tér- és időbeli „tartós pillantás” válik az egyén megfigyelésének elônyben részesített módozatává, illetve így pontosítja arra vonatkozó általános ismereteit, hogy egy adott kontextusban hogyan viselkedik. Meunier a dokumentumfilmhez 
hasonló identifikációs elköteleződés kapcsán egy olyan filmpéldáról ír, amely egy orvosra fókuszál, akit nézôként az „orvoslás” általános tevékenységeiben, kontextusaiban látunk. A dokumentumfilmes attitûd során, az adott orvosra egyszerisége és sajátosságai ellenére hajlamosak vagyunk úgy tekinteni, mint a többi orvos reprezentánsára, akik általában hasonló módon viselkednek. A képernyốn látható doktort tehát olyan személyként fogjuk fel, akit a logikában olykor „tipikus egyedinek” [typical particular] neveznek. ${ }^{[10]}$ A home movie kontextusában azonban a saját képi énünknek való episztemológiai elkötelezôdés másfajta fordulatot vesz (még akkor is, ha történetesen orvosok vagyunk), a mi azonosulásunk éppen fordított irányban múködik Meunier hasonlatához képest. Egy saját példával élve: van egy home movie-m a távoli múltból, amelyen a kétéves fiammal vagyok látható játék közben. Tekintettel arra, hogy akkoriban a gyermekemre és tudatosan nem önmagamra összpontosítottam, csak nagy általánosságban emlékszem a felvett eseményre. E régmúltbéli anyai jelenetet figyelvén a jelenbeli vágyam az, hogy többet „tudjak meg” magamról mint „anyáról” úgy, hogy a fiammal való interakció közben a képi énem sajátos motorikus viselkedését, testtartását és érzelmi reakcióit figyelem és értem meg. Ellentétben Meunier dokumentumfilmes orvosával, akit sok doktor reprezentánsának tartok, az én identifikációs szándékom e home movie kapcsán az, hogy kifejezetten „megkülönböztessem” magamat más anyáktól azon belül, amit az „anyaság” tevékenységeként és kontextusaként ismerek. Így a kísérteties ezen módja során a saját képi énemre irányított figyelmem kevésbé intenzív és korlátozott, mint az axiologikus kísérteties felbukkanásakor, ám a dokumentumfilmes attitűdhöz képest mégis intenzívebb lehet - utóbbi esetében „valós”, de számomra személyesen ismeretlen „másokat” nézek és ismerek meg, nem pedig „magamat”. A kísérteties tapasztalata ebben az esetben is módosítja Meunier fenomenológiájának jellemvonásait.

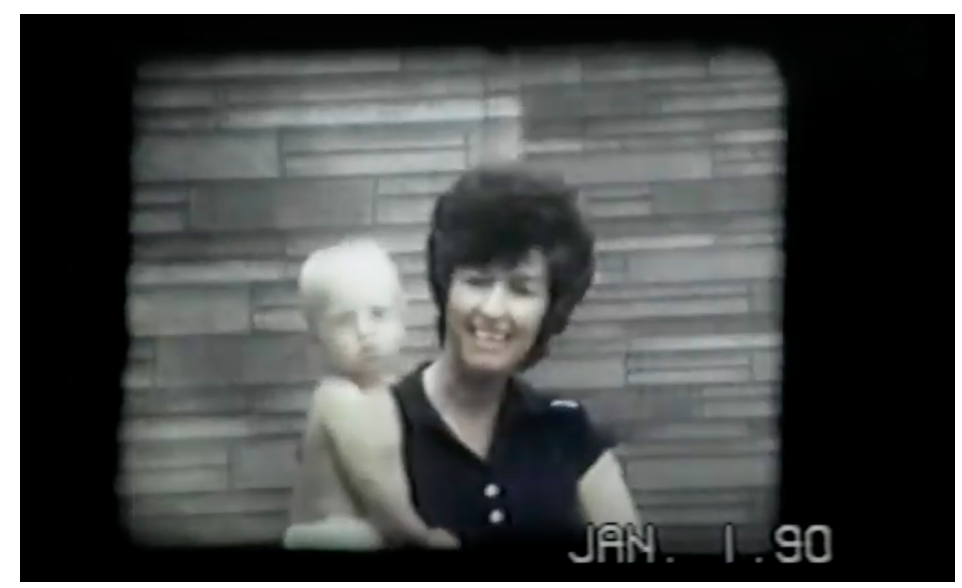

Anya gyermekével egy régi családi videón. URL: https://www.youtube.com/watch?v=HJ7X7SOn7mM

Összefoglalva, a home movie attitûdön belül történik elmozdulás a kevésbé sürgetô és érzelmi szempontból „hûvösebb” dokumentumfilmes attitûd felé, és ez nem teljes átlépés egyik attitûdbôl a másikba. Ehelyett ez egyfajta kompenzáló válasz arra a kísértetiesre, amely az episztemológiai újra-felimerést vagy a múltbéli képi én felvállalását vonja maga után egy inkább személytelenebb, mintsem személyes azonosulás során. Így tehát az episztemológiai kísérteties által elôidézett válság nem az axiologikus kísérteties esetében fellépô jelenbeli önészlelési krízis, hanem egy 
tágabb értelemben vett idóbeli válság, amely kiváltja annak a nyugtalanító tudatát, hogy saját önismeretünk mindig hiányos. E ponton Freud nagy hatású elődje, Ernst Jentsch meglátásai lehetnek találóak. Értelmezésében a kísérteties „feltétele az intellektuális bizonytalanság. A kísérteties lényegében olyasvalami lenne, amiben úgymond nem ismerjük ki magunkat." ${ }^{[11]} \mathrm{Az}$ intellektuális bizonytalanság az episztemológiai kísérteties tapasztalatában nem az „Ez tényleg én volnék?" hirtelen kérdésében manifesztálódik, hanem abban a törekvésben, hogy minél több „objektív” tudást szerezzünk „önmagunkról” - még akkor is, ha ez sosem lesz elegendô.

Ezzel elérkezünk az ontológiai kisértetieshez, amely során azt az egzisztenciális kérdést tesszük fel, hogy „Mi is vagyok én valójában?”. Ez a kísérteties leginkább nyomasztó és visszaható modalitása, bár nem feltétlenül kell váratlan fizikai benyomásként vagy intellektuális bizonytalanságként átélni. Meunier értelmezése alapján - amely szerint a home movie attitúd során sokkal inkább magunkkal foglalkozunk - az ontológiai kísérteties inkább tapasztalható meg úgy, mint egy „felfüggesztett” szembesülés nem csupán „önmagunkkal”, hanem az „ürességgel” is. (1969: 104) A home movie-s élmény e harmadik modalitása, amelyben az „Énként” megjelenó énkép szembekerül a „magamként” azonosítható képi énnel, a legkevésbé képernyőfüggô és a leginkább tevôlegesen létesítô. Úgy tûnik tehát, hogy az összes modalitás közül ez felel meg leginkább azoknak a fenomenológiai jellemzóknek, amelyek Meunier értelmezésében megkülönböztetik a home movie attitúdöt a dokumentumfilmhez és a fikcióhoz kapcsolt magatartásoktól. Mindazonáltal mégsem ez a helyzet. Az ontológiai kísérteties megjelenésekor a nézô ugyan túllép a képernyốn látható sajátosságokon és erôsen létesítô tevékenységet végez, ezek azonban a home movie attitûddel ellentétes intencionális irányba hatnak. Ahelyett, hogy kifelé, a képernyốn keresztülnéznénk rendkívüli létesítô, ám egyben hiábavaló erôfeszítéssel annak érdekében, hogy felidézzük mások ismerôs múltjának jelenlétét, tekintetünk a képernyốn látható átlátszatlan képi énrôl visszaverôdik, és saját magunk felé, befelé irányul. Ez a visszaható pillantás, amely elfordul a képernyôtôl saját „lényünk” mélyére, tulajdonképpen maga a „kiüresedett” én láthatatlan és kísérteties feltárulkozása. A képernyốn látható képi én, a képernyốn kívüli énkép és az e kettôt feltételezhetô kiterjesztéseként szolgáló Én mind-mind „helyrehozhatatlanul kikerül az irányításunk alól” (Meunier 1969: 105).

Az ontológiai kísérteties tapasztalatában a home movie attitúd temporalitása ismét megváltozik sôt, ebben az esetben teljesen át is alakul. A képernyốn megjelenô képi énnel való találkozás olyan nézôi élményt vált ki, amelynek jelenvalósága nem csak felerôsödik, hanem időben is kiterjedtté válik. Vagyis a jelen - ahelyett, hogy kizárná a retenció és a protenció idôbeliségét - inkább magába foglalja és sûríti azokat. Meunier kifejezésével élve tehát azt mondhatnánk, hogy az ontológiai kísértetiesben a nézô létesítô tevékenysége nem a képernyốn látható sajátosságok általánosításában rejlik, hanem inkább az idô szegmentálásának az általánosításában. A nézô ebben a temporális értelemben sûrú és kiterjeszthetô jelenben felfüggesztve fogja fel az ontológiai kísérteties jelentôségét, ahol a képernyôn látható képek már csak ürügyként szolgálnak a belsô revelációhoz. Annak a tudatosítása ez, hogy az ember sosem érheti utol saját „énjét”, mert „az” bármi is legyen „az” - egyrészt idôben mindig lemarad, ám másrészt meg is elôzi nem csupán a 
mi létünket, hanem a saját létét is. „Az” mindig mássá válik, mint ami (sosem) volt, van vagy lesz. Meunier „ürességével” szembesülve a nézô „énje” - bárhol is legyen - kiüresedik. A nézô nem csupán az önismeretébe, hanem az önmagába vetett bizonyosságától is megfosztatik, és egy téridôbeli szakadékban találja magát, illetve „magukat” (ez itt egy különösen terhelt többesszámú névmás). Ez egy aszinkron, de egyben megfordítható kettôsség is a látható képi én, az elképzelt énkép és a láthatatlan „Én” között, amelyben ezek viszonylagos különállósága és különbségei leomolnak, a talajt vesztett nézô pedig velük együtt bukik el.

E tekintetben az ontológiai kísérteties inkább a heideggeri megközelítéshez kapcsolódik, mintsem Jentsch vagy Freud elgondolásához. Amit Heidegger Umheimlichkeitnak (vagy kísértetiességnek) nevez, az nem fizikai érzés, intellektuális kétely vagy pszichológiai minôség. Értelmezésében ezek inkább származékai, semmint ontológiai tapasztalatai a kísérteties élményének. A kísérteties Heidegger számára eredendô; úgy tekint rá, mint egyfajta „alapnélküliségre”, amely - ha paradox módon is, de - az emberi létezés megalapozó szerkezete. A német filozófus szerint az ember alapvetően kísérteties, idegen és ismeretlen önmaga számára is: „a jelenlét és a hiány, az elrejtés és a feltárás, a rejtôzés és megjelenés ingatag keveréke, vagyis az ember otthonosságát pontosan az alapozza meg, hogy nincs otthon ebben a világban." ${ }^{[12]}$ Kétségkívül minden film (vagy videó) médiumjellegéból fakadóan - pontosan a jelenlét és a hiány, a leplezés és a leplezetlenség, a rejtőzködés és a megjelenés instabil megfordíthatóságának és ingadozásának tapasztalatát kínálja számunkra. A home movie azonban nemcsak formájává, hanem tartalmává is teszi ezt a fajta instabilitást. Így pedig sokunk számára - akik a képernyőn látható önmagunkkal találkozunk - a kísérteties nem csupán a home movie, hanem az emberi lét alapját is képezi.

Végezetül szükséges ismételten hangsúlyoznom, hogy jelen kutatásom a home movie e speciális esetével kapcsolatban a Meunier-féle filmes azonosulás fenomenológiája elôtti tiszteletadásként értendô. Vázlatos tömörsége ellenére - vagy talán éppen amiatt - Meunier a képernyővel kialakított aktív kapcsolatunk jellemzôiit a szubjektív tudás, attitûd, idôbeliség és affektus intencionális modalitásaival alapozza meg és írja le. A francia teoretikus tehát jelentôs egzisztenciális szókészletet biztosít a számunkra, amely megvilágító erejú összehasonlító módszert nyújt ahhoz, hogy elemezni tudjuk, miként éljük meg és differenciáljuk a filmélményt. Továbbá a kötete okozta heurisztikus élmény egyben felhívás is arra, hogy folytassuk e „megélt”, ám mindig „közvetített” tapasztalat felfedezését, annak számtalan történelmi, kulturális és esztétikai változatában.

Fordította Simor Kamilla A fordítást ellenôrizte Füzi Izabella 
[A szöveg eredeti megjelenési helye: Sobchack, Vivian: 'Me, Myself, and I': On the Uncanny in Home Movies. In The Structures of the Film Experience by Jean-Pierre Meunier. Historical Assessments and Phenomenological Expansions. Szerk. Hanich, Julian - Fairfax, Daniel. Amsterdam, Amsterdam University Press, 2019. 205-217. A fordítást a kiadó engedélyével tesszük közzé.]

\section{Jegyzetek}

1. Még ha néhány ember a képernyốn fizikailag jelen is van, a jelenben nem olyanok, mint akkor voltak; így jelenlétük alárendelôdik a minket (és valószínúleg ôket is) magába szippantó, emlékekkel átszôtt téridônek.

2. Kifejezetten kiemeli e neologizmusnak a memóriára helyezett hangsúlyát Marie-Aude Baronian: Remembering Cinema: On the film-souvenir. In The Structures of the Film Experience by Jean-Pierre Meunier. Historical Assessments and Phenomenological Expansions. Szerk. Hanich, Julian - Fairfax, Daniel. Amsterdam, Amsterdam University Press, 2019. 218-231.

3. Bôvebben lásd: Sobchack, Vivian: Toward a Phenomenology of Non-Fictional Film Experience. In Collecting Visible Evidence. Szerk. Renov, Michael-Gaines, Jane. Minnesota, University of Minnesota Press, 1999. 241-254.

4. A saját magunk rögzítésének problémáját egy másik megközelítésben lásd: Christian Ferencz-Flatz: You Talkin' to Me? On Filmic Identification in Video-Selfies. In The Structures of the Film Experience by JeanPierre Meunier. Historical Assessments and Phenomenological Expansions. Szerk. Hanich, Julian-Fairfax, Daniel. Amsterdam, Amsterdam University Press, 2019. 233-244.

5. Merleau-Ponty, Maurice: A látható és a láthatatlan. Ford. Farkas Henrik - Szabó Zsigmond. Budapest, L’Harmattan Kiadó - Szegedi Tudományegyetem Filozófiai Tanszék, 2007. 141. Sobchack hivatkozása: Merleau-Ponty, Maurice: The Visible and the Invisible. Ford. Lingis, Alphonso. Evanston, Northwestern University Press, 1969. 123. Merleau-Ponty azt a tágabb értelemben vett megállapítást teszi, hogy a világ nem egy különálló „tárgy”, sem pedig mi mint megtestesültek nem vagyunk különálló „szubjektumok”.

6. Az unheimlich kifejezés különbözôképpen reflektált kifejezéseihez lásd Freud, Sigmund: The Uncanny (1919). Ford. Strachey, James. In The Standard Edition of the Complete Psychological Works of Sigmund Freud, XVII. kötet (1917-1919): An Infantile Neurosis and Other Works. Szerk. uô. London, The Hogarth Press, 1955. 217-256. [Magyarul: A kísérteties. Ford. Bókay Antal - Erôs Ferenc. In Pszichoanalizis és irodalomtudomány. Szöveggyüjtemény. Szerk. Bókay Antal - Erôs Ferenc. Budapest, Filum Kiadó, 1998. 65-82.]; Jentsch, Ernst: On the Psychology of the Uncanny (1906). Ford. Sellars, Roy. Angelaki, 1997/1. 7-16.; és Martin Heidegger Unheimlichkeit terminusához lásd Withy, Katherine: Heidegger on Being Uncanny. Cambridge-Massachusetts-London, Harvard University Press, 2015.

7. „Do you feel uncomfortable watching yourself on video?” [Idézet a következô felhasználóktól: Pinko, Pet1986, Suzywong63, HungerCult, Shadow2009, KidRacchyy], Digital Spy, 2012.07.11. URL: https://forums.digitalspy.com/discussion/1691957/do-you-feel-uncomfortable-watching-yourself-onvideo [utolsó letöltés ideje: 2021. 08. 13.]

8. Bôvebben lásd: Masahiro Mori: The Uncanny Valley: The Original Essay by Masahiro Mori [1970]. Ford. MacDormand, Karl F. - Kageki, Norri. IEEE Robotics \& Automation Magazine, 2012/2. 98-100.; and Mita, H. Theodore - Dermer, Marshall - Knight, Jeffrey: Reversed Facial Images and the Mere-Exposure Hypothesis. Journal of Personality and Social Psychology, 1977/ 8. 597-601.; 9.

9. „Do you feel uncomfortable?” [Idézet a következô felhasználótól: Fluffymingo], Digital Spy.

10. Meunier nem használja a „tipikus egyedi” fogalmát, de a dokumentumfilmek „reprezentativitásáról” szóló 
elemzése mindenképpen indokolja ezt a kifejezést. Az általánosítás e módjáról bôvebben lásd: Alexander, Hubert: The Language and Logic of Philosophy. Albuquerque, University of New Mexico Press, 1967. 232.

11. Freud, Sigmund: i.m. 221. Magyar fordítás: i. m. 66.

12. Carman, Taylor: Heidegger on Being Uncanny, by Katherine Withy. European Journal of Philosophy, 2017/3. 901.

\section{Irodalomjegyzék}

- Alexander, Hubert (1967): The Language and Logic of Philosophy. Albuquerque, University of New Mexico Press.

- Baronian, Marie-Aude (2019): Remembering Cinema: On the film-souvenir. In The Structures of the Film Experience by Jean-Pierre Meunier. Historical Assessments and Phenomenological Expansions. Szerk. Hanich, Julian - Fairfax, Daniel. Amsterdam, Amsterdam University Press, 218-231.

https://doi.org/10.1515/9789048537846-011 https://doi.org/10.2307/j.ctvpbnq 82.13

- Carman, Taylor (2017): Heidegger on Being Uncanny, by Katherine Withy. European Journal of Philosophy, 2017/3.

- Ferencz-Flatz, Christian (2019): You Talkin' to Me? On Filmic Identification in Video-Selfies. In The Structures of the Film Experience by Jean-Pierre Meunier. Historical Assessments and Phenomenological Expansions. Szerk. Hanich, Julian-Fairfax, Daniel. Amsterdam, Amsterdam University Press, 233-244. https://doi.org/10.1515/9789048537846-012 https://doi.org/10.2307/j.ctvpbnq82.14

- Freud, Sigmund (1998): A kísérteties. Ford. Bókay Antal - Erôs Ferenc. In Pszichoanalízis és irodalomtudomány. Szöveggyújtemény. Szerk. Bókay Antal - Erôs Ferenc. Budapest, Filum Kiadó. 65-82.

- Hanich, Julian - Fairfax, Daniel (szerk.) (2019): The Structures of the Film Experience by Jean-Pierre Meunier. Historical Assessments and Phenomenological Expansions. Amsterdam, Amsterdam University Press. https://doi.org/10.2307/j.ctvpbnq82

- Jentsch, Ernst (1906/1997): On the Psychology of the Uncanny (1906). Ford. Sellars, Roy. Angelaki, 1997/1. 7-16.

https://doi.org/10.1080/09697259708571910

- Merleau-Ponty, Maurice (2007): A látható és a láthatatlan. Ford. Farkas Henrik - Szabó Zsigmond. Budapest, L'Harmattan Kiadó - Szegedi Tudományegyetem Filozófiai Tanszék.

- Meunier, Jean-Pierre (1969): Les structures de l'expérience filmique: L'identification filmique. Louvain, Vander.

- Mita, H. Theodore - Dermer, Marshall - Knight, Jeffrey (1977): Reversed Facial Images and the Mere-Exposure Hypothesis. Journal of Personality and Social Psychology, 1977/ 8. 597-601. https://doi.org/10.1037/0022-3514.35.8.597

- Mori, Masahiro (1970/2012): The Uncanny Valley: The Original Essay by Masahiro Mori [1970]. Ford. MacDormand, Karl F. - Kageki, Norri. IEEE Robotics \& Automation Magazine, 
2012/2. 98-100.

https://doi.org/10.1109/MRA.2012.2192811

- Sobchack, Vivian (1999): Toward a Phenomenology of Non-Fictional Film Experience. In Collecting Visible Evidence. Szerk. Renov, Michael-Gaines, Jane. Minnesota, University of Minnesota Press, 241-254.

- Withy, Katherine (2015): Heidegger on Being Uncanny. Cambridge-Massachusetts-London, Harvard University Press.

https://doi.org/10.4159/9780674286771 
(C) Apertúra, 2021. tél | www.apertura.hu

webcím: https://www.apertura.hu/2021/tel/sobchack-en-engem-es-magam-a-home-movie-

kiserteties-hatasarol/

https://doi.org/10.31176/apertura.2021.16.2.7

(Q)opertúro 